\title{
Комплексна корекція стресасоційованих розладів у студентів закладів вищої освіти з психотравмуючими подіями в анамнезі
}

\author{
A.I. Шарун \\ Дніпровський державний медичний університет, Дніпро, Україна
}

\begin{abstract}
Анотація. 3 метою впровадження медико-організаційних та лікувально-діагностичних підходів, які спрямовані на підвищення рівня здоров'я отримувачів вищої освіти в Україні, обстежено 249 студентів Дніпровського державного медичного університету та Дніпровського базового медичного коледжу з ознаками розладів адаптації та без них. Основну групу становили 159 респондентів з наявними в анамнезі психотравмуючими подіями, зокрема діти учасників антитерористичної операції і внутрішньо переміщені особи. Картина розладів адаптації була констеляцією симптомів, що відповідають критеріям афективних, невротичних, стресових і соматоформних розладів. Застосування лікувально-профілактичної тактики, що базується на принципах персоналізованої медицини, 3 використанням традиційних і нетрадиційних методів дозволяє активізувати природні механізми адаптації і підвищити стресостійкість. При аналізі отриманих даних виявлено, що специфічним та найбільш частим проявом невротичних розладів у студентів, які зазнали психоемоційного стресу, $є$ ситуаційно зумовлені реакції психічної дезадаптації. Після завершення інтеграційного втручання результати показали помітне поліпшення всіх показників, а саме - незначний рівень стресу, депресії і тривоги, покращання самопочуття. Результати 36-місячного катамнестичного дослідження свідчать про високу ефективність запропонованої системи корекції порушень адаптації у студентів групи високого ризику в процесі навчальної діяльності. Отримані дані можуть бути використані для впровадження ефективної системи комплексної корекції проявів психосоціальної дезадаптації та реабілітаційної роботи.
\end{abstract}

Ключові слова: розлади адаптації, стрес, студенти, медико-психологічна підтримка, психоосвіта, психотерапія, лікування.

\section{Вступ}

Сучасний період розвитку України характеризується значною кількістю соціально зумовлених стресогенних чинників, наслідком чого $\epsilon$ тенденція до негативних зрушень у стані здоров'я населення, серед яких одним з найбільш значимих $\epsilon$ збільшення кількості дезадаптивних станів та реакцій $[1,2]$.

Розлади адаптації - актуальна проблема сучасної психіатрії, що зумовлено їх високою поширеністю, труднощами верифікації, відсутністю стандартних схем лікування і негативними соціальними наслідками.

Особливо актуальною ця проблематика стала останнім часом в Україні, яка стикнулася із різким зростанням соціального напруження, викликаного бойовими діями в зоні проведення операції об'єднаних сил (OОC) та значною кількістю внутрішньо переміщених осіб [3].

Необхідність дослідження професійного розвитку лікарів випливає не тільки з необхідності теоретичного дослідження цього процесу, а й з нагальної потреби у вирішенні прикладних питань, актуальних для забезпечення процесу становлення суб'єкта професійного розвитку. Це можливо на основі цілісного комплексного вивчення особливостей професійного розвитку та формування психологічної адаптації майбутнього медичного працівника до професійної діяльності $[3,4]$.

Ефективне вирішення питання особливостей проявів механізмів розвитку дезадаптивних станів в умовах соціального стресу, оптимізація надання кваліфікованої медико-психологічної допомоги та психопрофілактики подібних хворобливих станів $\epsilon$ одними з пріоритетних завдань сучасної медицини $[5,6]$.

Мета: розроблення принципів комплексної персоніфікованої терапії, реабілітації та профілактики проявів розладів дезадаптації у студентів, що перенесли психоемоційний стрес.

\section{Об'єкт і методи дослідження}

На базі Дніпровського державного медичного університету та Дніпровського базового медичного коледжу з 249 студентів закладів вищої освіти медичного профілю віком > 18 років відібрано 159 осіб обох статей з середнім віком 20,88 22,0 року. Перші респонденти обстежені в листопаді 2018 р., а основна робота в цьому напрямі тривала до 2021 р. включно. Таким чином, зміни стану ре- єстрували продовж $\geq 3$ років - спочатку в осіб основної та контрольної груп (159 та 90 відповідно), а потім, за результатами попереднього скринінгу та обстеження, - у групі підвищеного ризику.

Для досягнення поставленої мети проведено комплексне клініко-анамнестичне, клініко-психопатологічне та психометричне обстеження. Дослідження здійснено відповідно до принципів біоетики, викладених у Гельсінській декларації «Етичні принципи медичних досліджень за участю людей» та «Загальної декларації про біоетику та права людини (ЮНЕСКО)». Під час роботи застосовували принципи добровільності, анонімності та довіри, всі учасники надали письмову усвідомлену згоду на участь у дослідженні.

Оцінку психічного стану проводили на підставі структурованого клінічного інтерв'ю. Додатково застосовували шкалу психологічного благополуччя (К. Ріфф, 1989, адаптація Т.Д. Шевеленкової, П.П. Фесенко, 2005); опитувальник Леонгарда Шмішека (H. Schmieschek, 1970); опитувальник вираженості психопатологічної симптоматики (Symptom CheckList-90-Revised, L.R. Derogatis, адаптація H.B. Тарабріної, 2001); шкалу астенічного стану (Л.Д. Малкова, за адаптацією Т.Г. Чортова на основі Міннесотського багатоаспектного особистісного опитувальника (Minnesota Multiphasic Personality Inventory - MMPI); показник якості життя; інтегративний тест тривожності (А.П. Бізюк та співавтори, 2005); опитувальник COPE (C.S. Carver et al., 1989, адаптація О.І. Рассказової та співавторів, 2013).

Математичну обробку даних здійснювали 3 використанням пакета комп'ютерних програм «Microsoft Excel 2010» i «STATISTICA 6.1» («StatSoft Inc.», № AGAR909E415822FA).

\section{Результати та їх обговорення}

У результаті дослідження діагностовано переважання високого рівня особистісної тривожності у студентів основної групи порівняно з контрольною за наступними шкалами:

- «емоційний дискомфорт» $(5,28)$ - виявлено знижений емоційний фон або незадоволеність життєвою ситуацією, емоційну напруженість, елементи ажитації, безпосередньо чи опосередковано пов'язані з наявністю емоційних розладів;

- «астенічного компонента тривожності» $(5,05)$ - переважання в структурі тривожності втоми, розладів сну, млявості і пасивності, швидкої стомлюваності; 
- «тривожна оцінка перспективи» $(4,93)$ - чітко простежується проєкція страхів, обернена в перспективу, загальна заклопотаність щодо майбутнього на тлі підвищеної емоційної чутливості (рис. 1).

Рисунок 1 Результати обстеження студентів основної та контрольної груп за допомогою інтегративного тесту тривожності (А.П. Бізюк та співавтори, 2005) у «сирих» балах

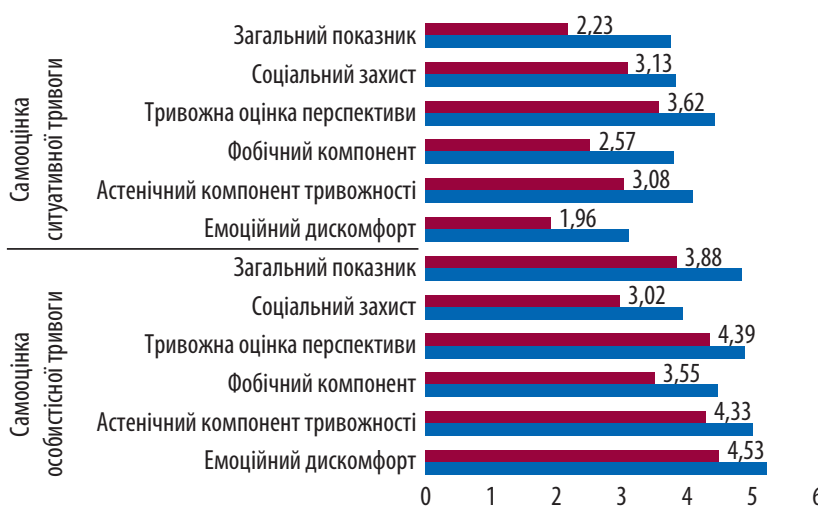

Загальні показники особистісної тривожності основної групи (4,88 порівняно з 3,88 в групі контролю) свідчать про високий рівень тривоги, наявність дезадаптації як в інтер-, так і в інтраіндивідуальних відносинах, а також про наявність дисгармонії з середовищем у цілому.

При інтерпретації отриманих результатів щодо ситуаційної тривожності на перший план виходить «тривожна оцінка перспективи» (4,47 в основній групі порівняно з 3,62 в контрольній), зовсім чітко простежуються проєкція страхів, обернена в перспективу, загальна заклопотаність щодо майбутнього на тлі підвищеної емоційної чутливості. У студентів основної групи також наявне підвищення показників «астенічний компонент тривожності» $(4,15)$, «соціальний захист» $(4,07)$ порівняно $з$ контрольною групою.

Виявлено зворотний кореляційний зв'язок між високим рівнем ситуативної $(r=-0,6)$ та особистісної тривоги $(r=-0,45)$ і низький рівень психічного благополуччя.

У результаті проведення аналізу отриманих показників вираженості психопатологічної симптоматики встановлено відмінності у студентів основної та контрольної груп за субшкалами опитувальника SCL-90 (табл. 1).

Основними клінічними проявами дезадаптивних розладів у студентів-медиків, що перенесли психоемоційний стрес, були зниження апетиту, порушення сну, швидка стомлюваність, слаб-

кість, постійна напруженість, занепокоєння, відчуття грудки в горлі, нав'язливі побоювання різного характеру, ірраціональні страхи, порушення концентрації уваги, когнітивні порушення, підвищена дратівливість, відчуття спустошеності, зниження працездатності, швидкості засвоєння нового матеріалу.

За результатами анкетування з'ясовано, що 53 (33,3\%) студенти основної групи, які проходили обстеження, вживали лікарські засоби з групи анксіолітиків. У групі контролю цей показник становив 9 (10\%).

У ході консультацій 61 (24,49\%) студенту, що проходить навчання, рекомендовано динамічне спостереження фахівцями медичної і психологічної служби з метою проведення з ними комплексу індивідуально орієнтованих заходів медико-психологічного супроводу. Частина респондентів, що потребували терапевтичних заходів, дали згоду на подальшу співпрацю. Усі студенти, що погодилися на продовження роботи, включені до динамічного спостереження впродовж 36 міс (з листопада 2018 до 2021 р.) (рис. 2).

Рисунок 2 Алгоритм лікувально-діагностичних та реабілітаційних заходів

Діагностичний етап

$\downarrow$

Діагностика на підставі критеріїв MКX-10

$\downarrow$

Визначення симптомівмішеней, специфічних для клінічної ситуації $\downarrow$

Визначення симптомівмішеней, специфічних для особи пацієнта

$$
\downarrow
$$

Реабілітаційний етап $\downarrow$

Психофармакологічне лікування пацієнтів з розладами адаптації відповідно до стандартів медичної допомоги при психічних розладах і розладах поведінки

Доповнимо наведені положення даними клінічного спостереження.

\section{Клінічний випадок}

Студент Д., 19 років.

Анамнез. Спадковість психічними захворюваннями родичів не обтяжена. Ріс і розвивався за віком, тяжких соматичних захворювань, лихоманок, травм у ранньому періоді життя не відмічено. Дитячих дошкільних установ не відвідував. У школі вчився задовільно.

Таблиця 1 Вираженість психопатологічної симптоматики у студентів основної та контрольної груп, за даними опитувальника SCL-90 (в балах)

\begin{tabular}{|c|c|c|c|c|c|c|c|c|c|}
\hline \multirow{2}{*}{$\begin{array}{l}\text { Симптоматична } \\
\text { категорія }\end{array}$} & \multicolumn{5}{|c|}{ Основна група } & \multicolumn{4}{|c|}{ Контрольна група } \\
\hline & $M \pm m$ & Me & $\min -\max$ & Q25-Q75 & $\mathbf{p}$ & $\mathrm{M} \pm \mathrm{m}$ & $\mathrm{Me}$ & $\min -\max$ & Q25-Q75 \\
\hline SOM & $0,50 \pm 0,06$ & 0,33 & $0-3,08$ & $0,08-0,58$ & 0,0066 & $0,28 \pm 0,05$ & 0,17 & $0-2,42$ & $0-0,42$ \\
\hline $0-C$ & $0,78 \pm 0,06$ & 0,60 & $0-3,10$ & $0,20-1,10$ & 0,0010 & $0,43 \pm 0,06$ & 0,25 & $0-2,50$ & $0,1-0,70$ \\
\hline INT & $0,78 \pm 0,07$ & 0,44 & $0-2,89$ & $0,22-1,11$ & 0,0002 & $0,36 \pm 0,05$ & 0,22 & $0-2,33$ & $0,11-0,44$ \\
\hline DEP & $0,63 \pm 0,06$ & 0,38 & $0-3,00$ & $0,15-1,00$ & 0,0004 & $0,30 \pm 0,05$ & 0,23 & $0-1,92$ & $0,08-0,38$ \\
\hline ANX & $0,49 \pm 0,05$ & 0,20 & $0-3,10$ & $0,10-0,70$ & 0,0001 & $0,21 \pm 0,05$ & 0,10 & $0-1,80$ & $0-0,20$ \\
\hline HOS & $0,54 \pm 0,05$ & 0,33 & $0-2,67$ & $0,17-0,83$ & 0,0007 & $0,26 \pm 0,04$ & 0,17 & $0-1,33$ & $0-0,38$ \\
\hline $\mathrm{PHOB}$ & $0,28 \pm 0,04$ & 0,00 & $0-2,43$ & $0-00,43$ & 0,0008 & $0,09 \pm 0,03$ & 0,00 & $0-1,29$ & $0-0,00$ \\
\hline PAR & $0,48 \pm 0,06$ & 0,17 & $0-2,67$ & $0-0,50$ & 0,0130 & $0,19 \pm 0,03$ & 0,17 & $0-1,00$ & $0-0,33$ \\
\hline PSY & $0,20 \pm 0,03$ & 0,10 & $0-1,20$ & $0-0,20$ & 0,0004 & $0,07 \pm 0,02$ & 0,00 & $0-0,90$ & $0-0,10$ \\
\hline $\mathrm{ADD}$ & $0,13 \pm 0,02$ & 0,06 & $0-0,88$ & $0-0,18$ & 0,0066 & $0,06 \pm 0,01$ & 0,03 & $0-0,35$ & $0-0,12$ \\
\hline GSI & $0,05 \pm 0,005$ & 0,04 & $0-0,24$ & $0,01-0,08$ & 0,0001 & $0,02 \pm 0,004$ & 0,02 & $0-0,16$ & $0,01-0,04$ \\
\hline PDSI & $26,81 \pm 1,76$ & 22,00 & $0-81,00$ & $9,0-40,00$ & 0,0005 & $17,22 \pm 2,2$ & 10,50 & $0-81,00$ & $6,75-22,00$ \\
\hline PSI & $0,15 \pm 0,01$ & 0,14 & $0-0,30$ & $0,12-0,20$ & 0,001 & $0,12 \pm 0,01$ & 0,12 & $0-0,25$ & $0,11-0,14$ \\
\hline
\end{tabular}

SOM (Somatization) — субшкала соматизації, 0-C (Obsessive-Compulsive) — субшкала обсесивно-компульсивності, INT (Interpersonal Sensitivity) — субшкала міжособистісної сенситивностi, DEP (Depression) — субшкала депресіi, ANX (Anxiety) — субшкала тривоги, HOS (Hostility) — субшкала ворожості, PHOB (Fobic Anxiety) — cyбшкала фобічної тривоги, PAR (Paranoid Ideation) - субшкала параноїдальних тенденцій, PSY (Psychoticism) — субшкала психотизму, ADD (Additional Items) — додаткові питання, GSI — загальний індекс, PDSI — індекс поточного симптоматичного дистресу, PSI — загальне число позитивних відповідей. 
Таблиця 2 Психологічний профіль студента Д., отриманий у результаті базової оцінки показників при проведенні психометричного обстеження

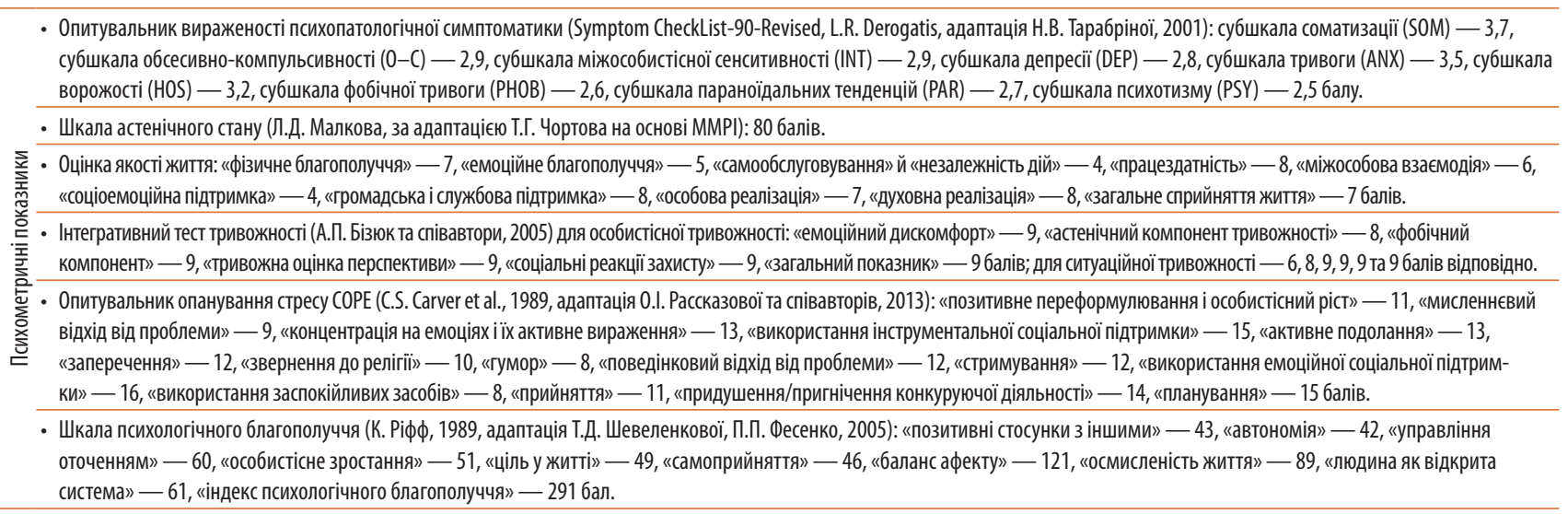

Родом із середніх соціально-економічних міських шарів. Мали місце проблеми адаптації, пов'язані зі зростанням стресу на тлі вимушеної зміни місця проживання у зв'язку з військовими діями на Сході України. Раніше проживав у м. Мирноград Донецької обл. Наразі проживає в житлі в найм у м. Дніпро.

Часто тривожиться, дратується, думає, що життя не виправдало його очікувань. Розповідає про минулі стосунки, які були припинені через зміну місця проживання. Через деякий час так і не зміг пристосуватися до способу життя і нового оточення. Намагався впоратися з труднощами, застосовував безрецептурні заспокійливі засоби, але стрес посилювався. 3 точки зору терапії, позитивним прогностичним чинником був рівень мотивації пацієнта до зміни життя. Негативним чинником виступали погані навички подолання.

Обстежений на початку 2020 та 2021 р. у зв'язку з незадоволенням психічним самопочуттям і зниженням якості життя.

Попередній діагноз: «Розлад адаптації з тривалою депресивною реакцією». Терапія, що ставить короткострокові і довгострокові цілі, з комплексним підходом, що використовує методи когнітивної поведінкової терапії та інтерперсональної психотерапії.

Оформлення. В одиничному випадку використовували експериментальне оформлення з попередньою і подальшою оцінкою змін у відповідь на втручання.

Процедура. Попередню оцінку проводили після вивчення симптомів, анамнезу, клінічних спостережень і психометричного обстеження (табл. 2).

На основі діагностики розроблений інтеграційний підхід до вирішення проблем і поліпшення якості життя. Після завершення програми послідувала пост-оцінка.

\section{Терапевтичні методи}

Психоосвіта. Специфічний розлад представлявся клінічним експертом пацієнтові та/або його сім'ї з тим, щоб вони могли отримати необхідні знання і навички і покращувати довгострокове управління проблемами, пов'язаними з хворобою і психосоціальною адаптацією.

Травмофокусована когнітивно-поведінкова терапія. Програма складалася в середньому з 45-хвилинних сеансів, що спочатку проводили 2 рази на тиждень, а потім 1 раз на тиждень впродовж 2 міс, та фармакотерапії. Усього проведено 12 сеансів в амбулаторному режимі. Застосовані техніки коупінгу, стабілізації, емоційної регуляції, когнітивне опрацювання, робота з коморбідними розладами та проблемами, повернення до життя, відновлення.

Фармакотерапія. Застосування мебікару з урахуванням наявності анксіолітичного, антифобічного, антидепресивного ефекту, ноотропної активності в середніх дозах (разова - 0,60,9 г, добова - 1,8-2,4 г).

Пост-оцінка: вираженість психопатологічної симптоматики SOM - 0,9; O-C - 1,1; INT - 1,3; DEP - 2,0; ANX - 0,9; HOS 0,5; PHOB - 0,1; PAR - 0,8; PSY - 0,7. Вираженість астенічних проявів - 48. Загальний показник особистісної тривожності становив 6, ситуаційної - 7 .

Результат. Після завершення інтеграційного втручання результати показали помітне поліпшення всіх показників, незначний рівень стресу, депресії і тривоги і поліпшення самопочуття.

\section{Висновки}

Результати 36-місячного катамнестичного дослідження свідчать про доволі високу ефективність запропонованої системи корекції порушень адаптації у студентів групи високого ризику в процесі навчальної діяльності. Отримані дані можуть бути використані для впровадження ефективної системи комплексної корекції проявів психосоціальної дезадаптації та реабілітаційної роботи.

\section{Список використаної літератури}

1. Маркова М.В., Козира П.В. (2015) Постстресові дезадаптивні стани на тлі соціальних змін: аналіз проблеми. Мед. психол., 1(37): 8-13.

2. Синайко В.М. (2002) Основні напрямки та клінічні особливості дезадаптації студентів ВУЗу. Експеримент. клін. мед., 1: 116-118.

3. Л Лсовий В.М., Капусник В.А., Марковський В.Д., Кожина Г.М. (2011) Порушення адаптації студентів першого курсу до навчальної діяльностіу Вищому навчальному закладі. Нові напрямки впровадження кредитно-модульної системи організації навчального процесу у вищих медичних і фармацевтичному навчальних закладах України II-IV рівнів акредитації: матеріали Всеукраїнської наукової навчально-методичної конференції, Медична освіта, 2: 78-79. D01:10.11603/me.v0i2.877.

4. Кожина А.М., Маркова М.В. (2017) Адаптація студентів першого курсу до навчальної діяльності - приоритетне завдання вищого навчального закладу. Междунар. психиатр. психотер. психоаналит. журн., 2(28): 28-34.

5. Кіосєва О.В. (2016) Психопатологическая характеристика эмоциональной сферы у студентов младших курсов. Укр. вісн. психоневрол., 1(86): 60-63.

6. Марков А.Р. (2016) Інтерперсонально-комунікативна складова в ґенезі дезадаптивних станів у цивільного населення вумовах інформаційно-психологічноїійни. Мед. психол., 11(4): $17-25$.

\section{Complex correction of stress- related disorders in students of higher education with a history of traumatic events}

\section{A.I. Sharun}

Dnipro state medical university, Dnipro, Ukraine

Abstract. In order to implement medical-organizational and medicaldiagnostic approaches aimed at improving the health of higher education recipients in Ukraine, 249 students of Dnipro state medical university and Dnipro basic medical college were examined with signs of adaptation disorders and without them. The main group consisted of 159 respondents with a history of traumatic events, including chil- 
dren of participants in the anti-terrorist operation and internally displaced persons. The picture of adaptation disorders was a constellation of symptoms that meet the criteria of affective, neurotic, stress and somatoform disorders. The use of treatment and prevention tactics based on the principles of personalized medicine, using traditional and non-traditional methods allows to activate the natural mechanisms of adaptation and increase stress resistance. The analysis of the obtained data revealed that the specific and most frequent manifestation of neurotic disorders in students who have experienced psycho-emotional stress are situation-related reactions of mental

\section{Інформація про автора:}

Шарун Анастасія Ігорівна — Дніпровський державний медичний університет, аспірант кафедри психіатрії, наркології і медичної психології, Дніпро, Україна. ORCID ID: 0000-0002-05678799

Адреса для кореспонденції:

Шарун Анастасія Ігорівна

49044, Дніпро, вул. В. Вернадського, 9

E-mail:drsharunai@gmail.com maladaptation. After the completion of the integration intervention, the results showed a marked improvement in all indicators, namely a slight level of stress, depression and anxiety, improved well-being. The results of a 36-month follow-up study indicate the high efficiency of the proposed system for the correction of adaptation disorders in high-risk students in the educational process. The obtained data can be used to implement an effective system of comprehensive correction of psychosocial maladaptation and rehabilitation work.

Key words: adaptation disorders, stress, students, medical and psychological support, psychoeducation, psychotherapy, treatment.

Information about the author:

Sharun Anastasiia I. - Dnipro State Medical University, postgraduate at the department of psychiatry, narcology and medical psychology, Dnipro, Ukraine. ORCID ID: 0000-0002-05678799

Address for correspondence:

Anastasiia Sharun

49044, Dnipro, V. Vernadsky st., 9

E-mail:drsharunai@gmail.com 